\title{
INDIGENOUS TOURISM MOVEMENTS
}

\author{
Edited by Alexis C. Bunten and Nelson H.H. Graburn
}

Critical studies of Indigenous culture and identity often conceive of cultural tourism as a mechanism by which members of dominant societies consume and appropriate the cultures of subaltern groups who are forced, through necessity, to participate in an industry that capitalizes on difference. However, cultural tourism is frequently marketed as an economic panacea for communities whose traditional ways of life have been compromised by the dominant societies with whom they are associated.

Indigenous societies are responding to these opportunities - or threats, depending on perspective - in innovative ways that set them apart from their non-Indigenous predecessors and competitors. Most Indigenousowned tourism venues are relatively young, and have been made possible through the growth of communications technology, the rapid expansion of domestic and international travel industries, and government policies intended to rectify multigenerational trauma resulting from past colonial engagements, assimilation, genocide, and slavery.

Using "movement" as a metaphor, this collection of essays uses tourism as a critical lens to explore the shifting identity politics of indigeneity in relation to heritage, global policy, and development. Through an examination of a range of contemporary case studies based in North America, South America, Asia, Africa, and Australia, the volume offers critical insights into the rapidly growing Indigenous tourism phenomenon.

ALEXIS C. BUNTEN manages the Indigeneity Program for the Bioneers Collective Heritage Institute based in San Francisco, California.

NELSON H.H. GRABURN is a professor emeritus in the Department of Anthropology at University of California, Berkeley. 
This page intentionally left blank 


\section{Indigenous Tourism Movements}

EDITED BY ALEXIS C. BUNTEN AND NELSON H.H. GRABURN

UNIVERSITY OF TORONTO PRESS

Toronto Buffalo London 
(C) University of Toronto Press 2018

Toronto Buffalo London

www.utorontopress.com

Printed in Canada

ISBN 978-1-4426-5019-0 (cloth)ＩSBN 978-1-4426-2829-8 (paper)

(6) Printed on acid-free, 100\% post-consumer recycled paper with vegetable-based inks.

\section{Library and Archives Canada Cataloguing in Publication}

Indigenous tourism movements / edited by Alexis C. Bunten and Nelson H.H. Graburn.

Includes bibliographical references and index.

ISBN 978-1-4426-5019-0 (cloth). - ISBN 978-1-4426-2829-8 (paper)

1. Heritage tourism - Case studies. 2. Indigenous peoples - Case studies.

I. Bunten, Alexis C., editor II. Graburn, Nelson H.H., editor

$$
\text { G156.5.H47I53 } 2018 \quad 338.4^{\prime} 79104089 \quad \text { C2017-906402-9 }
$$

University of Toronto Press acknowledges the financial assistance to its publishing program of the Canada Council for the Arts and the Ontario Arts Council, an agency of the Government of Ontario.

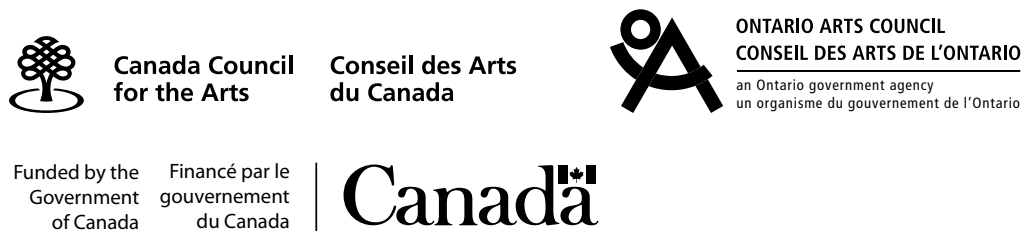

